\title{
Comparative Analysis of Agricultural Credit System and Organization in Selected Countries
}

\author{
Erdogan Gunes ${ }^{1}$, Hormoz Movassaghi ${ }^{2,}$ * \\ ${ }^{1}$ Department of Agricultural Economics, Ankara University, Ankara, Turkey \\ ${ }^{2}$ Department of Finance and International Business, Ithaca College, Ithaca, USA
}

Email address:

egunes@agri.ankara.edu.tr(E. Gunes),hormoz@ithaca.edu (H. Movassaghi)

${ }^{*}$ Corresponding author

\section{To cite this article:}

Erdogan Gunes, Hormoz Movassaghi. Comparative Analysis of Agricultural Credit System and Organization in Selected Countries. International Journal of Applied Agricultural Sciences. Vol. 3, No. 5, 2017, pp. 123-135. doi: 10.11648/j.ijaas.20170305.14

Received: June 26, 2017; Accepted: July 19, 2017; Published: September 9, 2017

\begin{abstract}
The agricultural sector has been a key economic force in all countries, developed and developing alike. To assist farmers with their financing needs, countries have established different agricultural credit systems and organizations depending on their overall needs, goals, and historical contextual background. Such structural considerations as the aggregate size of farm lands, diversity in production systems, and farmers' needs and wants have played an important role in shaping the evolution of agricultural credit organizations around the world. In this study, the agricultural credit systems in select developed and developing countries which offer a mix of very advanced, intermediate, and evolving systems are compared. This research aims to identify key difference of agricultural credit systems with regards to the main actors involved (governmental/private banks, credit cooperative, etc.), application processes, terms and conditions, types, and priorities. The study identifies several agricultural credit systems which reflect countries' political, economic and structural properties.
\end{abstract}

Keywords: Agricultural Credit Systems, Financial Institutions, USA, Emerging Economies

\section{Introduction}

Agricultural credit is very important in farms' development during production, marketing and other farming activities. It acts as an enabling and critical input in agricultural production process. Agricultural credit is very important for the growth of the farming sector. In order to utilize its full potential, farmer's education should be increased and their management ability will need to be developed by information and field training. They will need more technical and operating information and communication technology during the credit usage. In general, usage of credit has increased over time influenced by the socio-economic conditions and farming activities from country to country. Agricultural credit plays a significant role in the adoption of modern technologies and improvement of production system in the farming sector and, by extension, the economic development of rural areas. Most countries want to improve their agricultural production using credit facilities. Some governments, in both developed and developing countries, have offered a portfolio of credit options in order to increase farmers' financial power. On the other hand, some countries, especially in the under developed group, lack adequate financial resources to assist farmers at all or in meaningful ways.

There are extensive literature and macro analysis reports of farm credit system in few countries conducted by banks and government agencies. Monke [1] mentioned about US Farm Credit System to provide a permanent, reliable source of credit to U.S. agriculture since 1916. And this system consists of The USDA Farm Service Agency (FSA), The Farm Credit System (FCS) and Farmer Mac and other sources such as commercial banks, life insurance companies, individuals, merchants, and dealers. In the US farm credit system, Funding Corporation, part of the Farm Credit System, manages funding programs designed to satisfy System Banks' financing and risk-management needs while responding to market changes and investor demand, is very important to survive [2].

India is another important country in terms of difference of farm credit system. Kumar [3] noted that the majority of 
formal credit in rural India is disbursed through cooperative and commercial banks. Commercial banks are large and centralized entities under the direct supervision of the Reserve Bank of India (RBI), whose lending is expected to conform to affirmative action policies and targets. Cooperative banks, in contrast, constitute a large network of decentralized, independent entities, many aspects of whose functioning are not directly controlled by the RBI. Rural credit is an important source of funding for Brazilian agriculture, as well as a key policy instrument in the country. Rural credit is subsidized by the government and the rural credit portfolio is proposed by the federal government and is carried out by official banks and credit cooperatives totaling $\$ 38.5$ billion for all of Brazil [4]. Total loans to farmers by the government reached $\$ 57$ billion in 2013. Credit provided to commercial farmers continues to increase, with $85 \%$ of total credit allocated to large-scale farmers and only $15 \%$ to small-scale agriculture [5]. Tang et al. [6] emphasized that informal credit had the advantages of low or zero interest rates, flexible borrowing terms, and few restrictions on how the loans is to be used. This was one of the unique aspects of China's rural finance. However, with the rapid economic growth, informal credit supply may not be sufficient to meet the increased demand for relatively larger amount of credit as farmers start to engage in more diversified or more capital intensive economic activities (e.g. high valued crops and non-farm business activities). Tang et al. [6] focuses on the evolving rural credit market in China, where borrowing from the social network has been common but the recent economic transition has made this informal credit market inadequate in addressing rural credit needs. Turvey et al. [7] investigated the economic significance of informal borrowing between friends and relatives in rural China. Han [8] emphasized that the total amount of government budget allocated to agriculture and rural areas is low, the extent of support for rural credit insufficient, and the credit structure by rural financial institutions unbalanced in China. Scott and Druschel [9] analyzed the institutional fundamentals needed to achieve commercially sustainable rural financial services in China. Swinnen and Gow [10], analyzed credit subsidies, loan guarantees and specialized agricultural lending institutions and their problems in Central and Eastern Europe during the transition to a market economy. In that article, they showed why these problems may cause transaction costs to be so high that credit rationing and high interest rates are rational and efficient responses by lenders to the imperfect information problems of the agricultural sector. Jansson et al. [11] investigated the regulations of the credit market, government support and main creditors in some EU countries. There are many agricultural credit sources, classified as formal and informal generally. Although some are regulated in the financial market, informal agricultural sources are highly important in some countries such as Nigeria, India, Vietnam, Turkey $[12,13,14)$. Tanrıvermis and Bayaner [15] investigated formal and informal agricultural credit system in Turkey. They indicated that formal credit system in the form of banks and Agricultural Credit
Cooperatives (ACCs) have an important role in financing small scale farms in Turkey. They found ACCs efforts insufficient to modernize agriculture mainly due to emerging problems in the areas of social capital, moral hazard, and asymmetric information. Bojnec [16] analyzed agricultural and rural capital markets share similarities in three EU candidate market: Turkey, Croatia and FYP of Macedonia. Credit constraints form a limited access to finance for small scale individual farms in these countries. That is why remittances and donor funds have also played an important role in the agricultural and rural economy investments. Nwaru et al. [17] observed that credit facilitated adoption of innovations, led to increased farm productivity and income, encouraged capital formation and improved marketing efficiency in Nigeria. Etonihu et al. [18] observed that education, distance to source of credit and types of credit source were significant factors affecting farmers' accessibility to agricultural credit. Hence, government policy that intends to improve the accessibility to agricultural credit facilities should create enabling environment to ease farmers' access to education and credit facilities. Production efficiency of the credit user was found high but the resources were utilized inefficiently in Pakistan [19].

\section{Material and Methods}

This research started with collection of data and related information from books, annual reports, financial institutions, journals and web sites. It tried to examine farm credit system of some countries by searching literature. A number of countries were selected based on the ranking of their agricultural production value and were investigated for their agricultural credit organization and applications. The sample selected for this study include some developed and developing countries, namely: US, China, India, Brazil, Pakistan, African countries and Turkey.

\section{Results and Discussion}

There exists certain agricultural credit structure and organization systems in the selected countries for this study. Finance and credit have become critical components of agriculture because of the nature of front-end funding of growing crops, cyclical weather patterns and the national security aspects of agriculture [20].

\subsection{United States}

The agricultural sector has been a key economic force in the U.S. economy and is strongly affected by domestic and global economic conditions. The System was created to provide support for this sector because of its significance to the well-being of the U.S. economy and the U.S. consumer. The Farm Credit System (FCS) was established to provide a permanent, reliable source of credit to U.S. agriculture in 1916 [1]. The FCS has a statutory mandate to serve agriculture, and certain agribusinesses and rural homeowners. Borrowers must meet certain eligibility requirements in 
addition to general creditworthiness. Eligible borrowers and the scope of their financing can be grouped into four categories [21]:

a Full-time farmers. For individuals with over $50 \%$ of their assets and income from agriculture, FCS can lend for all agricultural, family, and non-agricultural needs (including vehicles, education, home improvements, and vacation expenses).

b Part-time farmers. For individuals who own farmland or produce agricultural products but earn less than $50 \%$ of their income from agriculture, FCS can lend for all agricultural and family needs. However, nonagricultural lending is limited.

c Farming-related businesses. FCS can lend to businesses that process or market farm, ranch, or aquatic products if more than $50 \%$ of the business is owned by farmers who provide at least some of the "throughput." FCS also can lend to businesses that provide services to farmers and ranchers (but not aquatic producers), such as crop spraying and cotton ginning. The extent of financing is based on the amount of the business's farmrelated income.

d Rural homeowners. FCS can lend for the purchase, construction, improvement, or refinancing of singlefamily dwellings in rural areas.

In US, the federal government has a long history of providing credit assistance to farmers. This system has three main organization:

a The USDA Farm Service Agency (FSA)

b The Farm Credit System (FCS) and Farmer Mac

c Other sources of credit for the agricultural sector include commercial banks, life insurance companies, and individuals, merchants, and dealers [1].

US Farm Credit System has collaboration with some institutions. And this system is controlled by Congressional Agricultural Committee. Farm Credit System was established by Congress in 1916 to provide a dependable and affordable source of credit to rural areas at a time when commercial lenders avoided farm loans. This system is not a government agency or guaranteed by the U.S. government [22]. Statute and oversight by the agriculture committees determine the scope of FCS activity, and provide benefits such as tax exemptions. The system is regulated by the Farm Credit Administration (FCA). The Farm Credit Administration sets minimum regulatory capital requirements for banks and associations and its regulations on liquidity set forth requirements for the banks to:

a Improve their capacity to pay their obligations and fund their operations by maintaining adequate liquidity to withstand various market disruptions and adverse economic or financial conditions;

b Strengthen liquidity management;

c Enhance the liquidity of assets they hold in their liquidity reserves;

d Maintain a three-tiered liquidity reserve;

e Strengthen their Contingency Funding Plan [23].

FCS system is not a lender of last resort; it is a for-profit lender with a statutory mandate to serve agriculture. Funds are raised through the sale of bonds in Wall Street. Four large banks allocate these funds to 76 credit associations that, in turn, make loans to eligible creditworthy borrowers [22]. The number of banks and associations has been declining for decades through mergers and reorganizations. The FCS holds nearly $41 \%$ of the farm sector's total debt (slightly higher than the nearly $40 \%$ share of commercial banks) and has the largest share of farm real estate loans $(46 \%)$. As of September 2014, FCS had \$208 billion in loans outstanding, of which about $46 \%$ was in long term agricultural real estate loans, $22 \%$ in short- and intermediate-term agricultural loans, $14 \%$ in loans to agribusinesses, $8 \%$ in energy and water/waste water loans, $4 \%$ in export financing loans and leases, $3 \%$ in rural home loans, and $2 \%$ in communications loans [24].

Figure 1 depicts the overall structure and ownership of the System. The System has a unique and highly successful cooperative structure. As a cooperative network, ownership begins with borrowers. The Funding Corporation, as agent for the banks, issues and markets System wide debt securities in order to raise funds for the lending activities and operations of the banks and associations. Farm Credit System Associations offer loans, leases and financial services to qualified borrowers. Farm Credit System Banks (Banks) provide capital to those retail associations. FCS is composed of four regional banks that provide funds and support services to 76 smaller Agricultural Credit Associations (ACAs), Federal Land Credit Associations (FLCAs), and Production Credit Associations (PCAs) [24]. Unlike the others, CoBank provides direct financing to large agribusinesses, cooperatives and rural utilities. All institutions in the Farm Credit System, including the Funding Corporation, are examined and regulated by the Farm Credit Administration, the System's safety and soundness regulator $[25,26]$. These associations provide loans to farmers' ranchers, rural home owners and eligible borrowers (Figure 1; $\mathrm{FCB}=$ Farm Credit Bank, ACB=Agriculture Credit Bank).

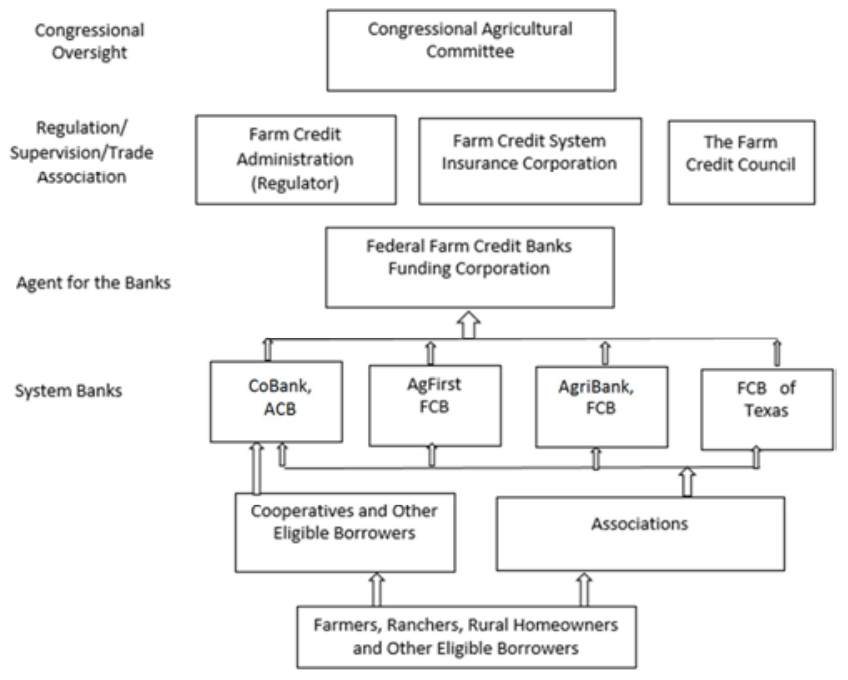

Figure 1. Cooperative Structure of the US Farm Credit System [27]. 
Other sources of credit for agriculture include commercial banks, life insurance companies, individuals, merchants, and dealers, which provide $63 \%$ of total farm debt without federal support or mandate. Commercial banks provide most of the loans to farmers through both small community banks and large multibank institutions [28, 29]. Historically, life insurance companies have also looked to farm real estate mortgages for diversification. Another important category of lenders is "individuals and others." This category consists of seller-financed and personal loans from private individuals, and the growing business segment of "captive financing" by equipment dealers and input suppliers.

\subsection{China}

China's rural financial system has changed dramatically over the last twenty five years, but rural financial reforms were lagging behind changes in the real economy and required further economic transition. As in some countries moving towards a market economy, the reform of banking systems and the creation of efficient financial markets in China continues to be among the most difficult reform issues. Poorly functioning official financial markets push rural population to rely on informal institutions. Access to credit is particularly difficult for small-scale farmers. According to a recent national survey of rural families, only $16 \%$ of farmers have recourse to formal or informal credit. This is partly due to the lack of collateral (the land belongs to collectives) and the high transaction costs involved in obtaining formal credit, but also results from the closing of many local branches of financial institutions and the failure of new ones to emerge. As a result, more than $70 \%$ of the loans are obtained through informal channels while less than $30 \%$ are from financial institutions [30].

China has a large population of which, $57.01 \%$ live in rural areas. Most of the rural population relies on agriculture sector. Although over $40 \%$ of the Chinese population works in agriculture, the agricultural sector contributes only $15 \%$ of the GDP. Around $60 \%$ of the added value of the agricultural sector stems from arable farming, followed by animal husbandry (24\%), fisheries (9\%) and horticulture and forestry (both 4\%) [31]. Financial sector reform began in the late 1970s in China. Because of the small scale, most farms show limited borrowing capacity, although many families have also non-farm income sources. In 1979, the "household responsibility system" began a new era for China's agriculture and entire economy, symbolizing the start of economic reforms, allowing the individual households to "own" the land for 15 years, which has now been extended to another 30 years and longer. The households can make their own decision to produce and deal with the surplus [6]. The "household responsibility system" plays a very important role in enhancing incentives and promoting efficient production and has increased agricultural output by $45 \%$ during the period of 1979 through 1984, when the first stage of reform was implemented [32]. The fast growing economy has generated increased credit demand, arising from both production and consumption needs of rural households. This has resulted in increased interactions between the households and financial institutions.

China has substantially boosted lending to farmers and agribusinesses in recent years. The balance of loans to farmers doubled between 2001 and 2005. China's agricultural loan balance reached the equivalent of $\$ 145$ billion in September 2005. Rural credit cooperatives (RCCs) and banks that lend to agriculture are being reformed and commercialized but agricultural lending is still largely policy-driven [33]. The system of rural finance in China is actually composed of three kinds of financial organizations and institutions. The first consists of state financial institutions; the second is the system of non-banking financial institutions, and the third is the unofficial funding organizations (Figure 2). The RCCs are dealing with the banking business, but they have always been regarded as financial institutions of a non-banking character in China.

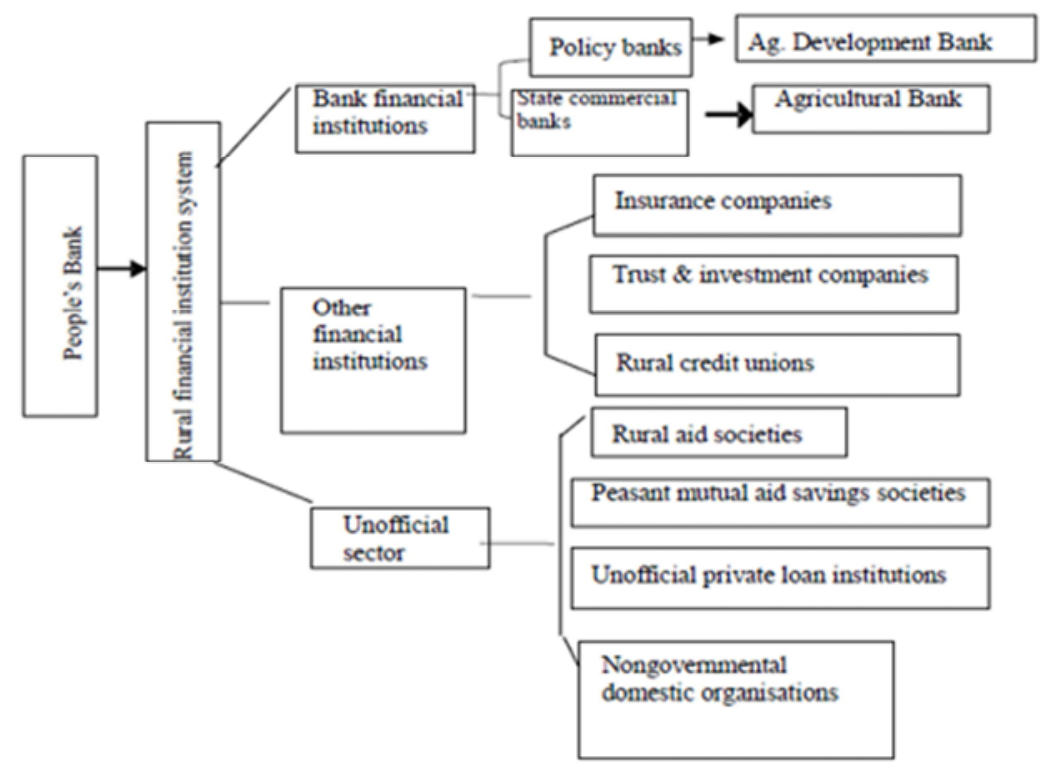

Figure 2. Structure of the Rural Financial Organization System in China [34]. 
China's banking system and interest rates are regulated by the central government. The financial system was originally designed to serve the State-Owned Enterprises (SOEs) and the banks lent money to the SOE sector at below-market rates. Chinese banking system is based on a four-tier system as described below [31]:

i. Four state-owned commercial banks (67\% market share): Agricultural Bank of China, Bank of China, China Construction Bank, and Industrial and Commercial Bank of China

ii. Three policy banks or specialized banks, established by the government in 1993 to take over the policy lending function of the 1st tier banks (10\% market share): Export-Import Bank, Agricultural Development Bank of China, and China Development Bank.

iii. Ten nation-wide joint-stock commercial banks (JSCBs) and commercial banks. Equity ownerships are distributed among the state and corporate enterprises (one exception is Minsheng Bank with $100 \%$ private capital).

iv. Large number of city commercial banks, urban credit co-operatives, rural credit co-operatives, foreign financial institutions, trust and investment companies, finance companies, and leasing companies.

China is implementing the "New countryside" policy. It is widely believed that more than one trillion yuan of funds will be needed by the year of 2020 in China in this process $[6,35]$. According to recent statistics, only $10.9 \%$ of loan is used in the rural areas in China, which means the majorities of farmers do not have access or do not borrow in formal credit market and could only borrow in their social networks such as friends and relatives. Most rural households in China rely on informal credit market to meet their credit needs. According to the literature, noninstitutional sources contribute roughly half of the credit volume in rural areas [36]. Feder et al. [37] reported that non-institutional credit shares were between one-third and two-thirds in several study areas. Yao and Chen [38] estimated that among all 240 million rural families, only $15 \%$ get loans from formal credit markets. To address these problems, the Chinese governments has set up credit programs aimed at improving rural households' access to credit, similar to what other countries did over the past 40 years. But most of the programs were not successful. The Agricultural Development Bank of China (ADBC), the Agricultural Bank of China (ABC) and Rural Credit Cooperatives (RCCs) are the three main financial institutions serving Chinese agriculture and the countryside. The government's policy to support credit in agriculture is mainly realized through these three financial institutions [8]. The Agricultural Development Bank (ADB) that provide credit at subsidized interest rates has failed both to achieve its objectives to serve the rural poor and to stay sustainable as a credit institution. The Rural Credit Cooperatives (RCC), the main access to credit for households in rural China, provided $87.5 \%$ of loans among all the rural financial institutions by June 2005 [39]. The deposits in RCCs were 30,694 million yuan (4,831 Million US dollar) by 2005 while the loan granted by RCCs was only 21,968 million yuan (3,485 Million US dollar), with a difference of 8,726 million yuan (1374 Million US dollar). It can be seen that even the largest rural financial institutions are not providing adequate financial service (loans) to rural households. The Postal Savings Bank of China (PSBC), the so-called "water pumps", provided no loans to rural households before March 2006 when the reform started. The $\mathrm{ABC}$, the biggest commercial agricultural bank, has always been focusing on the city market before 2007. Tang et al. [6] show the extent of credit demand and constraints in the rural households in China and provide explanations based on their survey study. OECD [30] organized a workshop about China's rural finance and credit infrastructure to identify problems and suggest policies and approaches to develop a wellfunctioning and sustainable agricultural and rural finance system. The main messages of these studies are to create a network of financial institutions and to establish an adequate legal financial framework. Rural Credit Cooperatives (RCCs) should also be self-sustainable institutions, capable of constant innovation to withstand competition of commercial banks. In order to formulate an integrated approach and action plan to rebuild China's rural financial system through the restructuring of the existing rural credit co-operatives, it is worthwhile to study the lessons learned from European Co-operative banking experience [27]. Also, the government should create a favorable environment for financial markets to facilitate savings and investment by efficient investors to minimize uncertainty and reduce transaction costs in financial and credit markets and to establish an effective supervision to protect depositors [30].

\subsection{India}

Agriculture plays a crucial role in the development of the Indian economy. Rural finance is a matter of credit concern in a developing economy like India where $70 \%$ of the population depends upon agriculture [40]. It accounts for about $19 \%$ of India's GDP. The importance of farm credit as a critical input to agriculture is reinforced by the unique role of Indian agriculture in the macroeconomic framework and its role in poverty alleviation [41]. Recognizing the importance of agriculture sector in India's development, the Government and the Reserve Bank of India (RBI) have played a vital role in creating a broad-based institutional framework to increase credit in that sector [42]. There are two main sources of agricultural credit in India [14]:

a Institutional sources: The institutional sector comprises government, co-operative, commercial banks and regional rural banks. There is large control of government on the activities carried out by these institutions.

b Non-Institutional sources: The non-institutional sector 
consists mainly of the professional and nonprofessional moneylenders, relatives and friends of the farmers.

The relative importance and role of these agencies has been a function of several historical and socioeconomic variables. In the context of development planning, a deliberate attempt is made by the state to gradually expand the institutional agencies. The institutional structure for agricultural credit is presented in Figure 3. As seen, the structure of agricultural credit system of India is comprised of government of India and reserve bank of India at the top and a wide network of commercial bank, co-operatives and regional rural banks below them. Rural co-operative credit institution consists of a two tier long-term credit structure and three tire short-term credit structure. Long term credit structure consists of state level co-operative agriculture and rural development bank. At village level, there is primary cooperative agriculture and rural development banks. Short term credit structure consists of state cooperative banks at the state level, district central co-operative banks at the district level and primary agricultural credit societies at village level $[43,14]$.

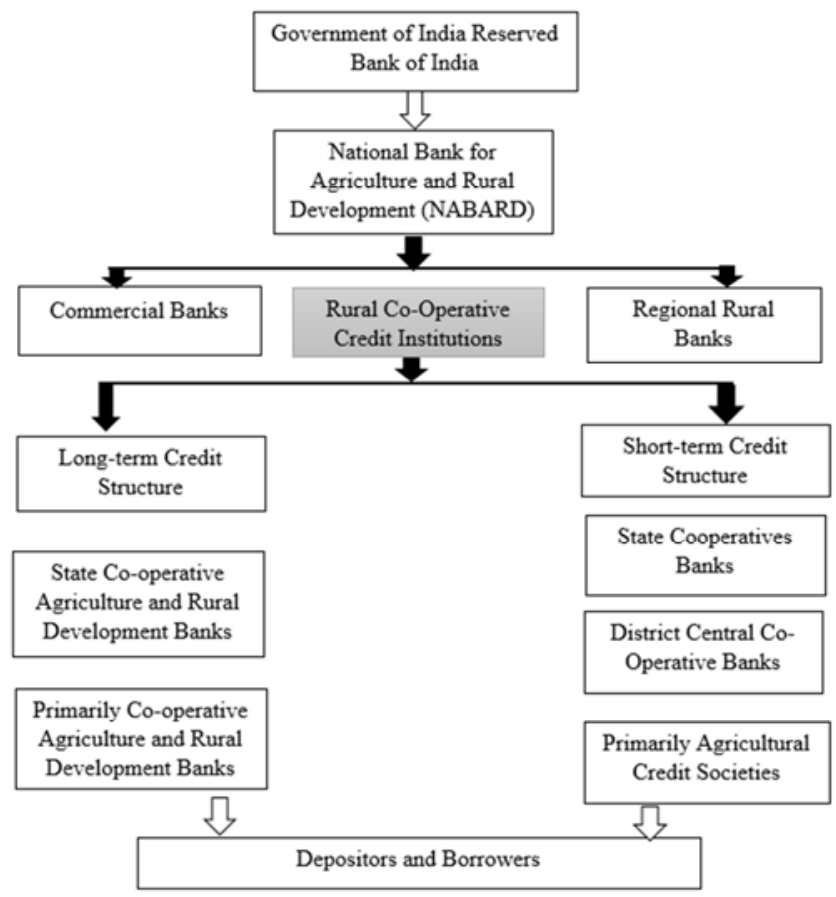

Figure 3. Organization and Institutional Structure of Agricultural Credit India [43].

When we look at the changes from non-institutional agencies to institutional credit sources in India during 19512011 , it is obvious that institutional agencies contributed $60.6 \%$ of the cash borrowings of the agricultural household in 2011 as opposed to $7.3 \%$ in 1951. Among the institutional agencies, the share of debt due to the cooperative and the commercial banks in the total debt was $52.8 \%$ in 2011 , in contrast to $4.2 \%$ in 1951 and $58.8 \%$ in 1991; it further declined to $52.8 \%$ in 2011 . The share of debt due to government and other formal sources was almost the same ratio. Debt owed to non- institutional agencies which formed $92.7 \%$ of the total debt in 1951, declined to $37.7 \%$ 2011; the decline was noticed in respect of each of the non-institutional agencies. Agricultural credit development strategy is still addressing institutionalization of credit at farmers' level in marketing, trade, processing and agribusiness. As a result of efforts in the agriculture credit delivery system, the share of private money lenders has decreased substantially from $69 \%$ in the early 1950 s to $18.2 \%$ by 2011 [44].

Some measures must be considered in order to develop agricultural credit in India. Firstly, co-operative credit structure needs revamping in order to improve the efficiency of the credit delivery system in rural areas. Unfortunately, an assessment of agriculture credit situation brings out the fact that the credit delivery to the agriculture sector continues to be inadequate. It appears that the banking system is still hesitant to purvey credit to small and marginal farmers. Secondly, the situation calls for concerted efforts to augment the flow of credit to agriculture, alongside exploring new innovations in product design and methods of delivery, through better use of technology and related processes. Facilitating credit through processors, input dealers, NGOs that are vertically integrated with the farmers, including through contract farming, in order to provide them critical inputs or process their produce could increase the credit flow to agriculture significantly. Thirdly, the competition and search for higher returns has made commercial banks explore profitable avenues and activities for lending such as financing of contract farming, extending credit to the value chain, financing traders and other intermediaries, which need to be encouraged. While the institutional systems and products such as futures markets and weather insurance have great potential to minimize the risk of lending, the process of their development needs to be carried forward [41].

In short, to improve the flow of credit to the agricultural sector, commercial banks need to find innovative ways of reaching out to the farmers, RRBs need to leverage their comparative advantage and cooperatives have to improve their governance structures. Meanwhile, as the premiere public institution in agricultural credit, NABARD's role is crucial in this regard [45].

\subsection{Pakistan}

Pakistan is basically an agricultural country and at present this sector accounts for $22 \%$ of its GDP. More than half of the population of Pakistan lives in rural areas, and agriculture is a key contributor to employment, income generation, exports and GDP. One of the major factors hindering the adoption of modern technologies and enhancement of productivity and development in the rural sector was lack of credit or capital constraints faced by farmers in achieving their full potential in production and marketing of farm products in Pakistan. The institutional agriculture credit was positively impacting the agriculture productivity in Pakistan [19].

The rural financial market in Pakistan is comprised of two 
components, i.e., the formal and informal. The formal component includes: The Zarai Tarqaiti Bank Limited (ZTBL), Commercial Banks, the Federal Banks for Cooperative (FBC) and other financial institutions engaged in rural lending. The informal sources are composed of commission agents, input dealers, professional moneylenders and landlords. The informal sector extends loans in the form of cash and in-kind for both consumption and production. This was the basic reason for the dominance of informal sector in rural credit market in Pakistan. This is evident from the 1996 Rural Credit Survey 1996 in which only 22\% of the rural households borrowed from formal sources. According to Pakistan Rural Household Survey, in 2001, the informal loans from friends and relatives had reached $61 \%$ in more recent times [19]. Ratio of commercial bank credit in total agricultural credit has increased more rapidly in recent years resulting from the significant changes in credit policy during the last few years. The performance of cooperatives has however, remained unsatisfactory. Government's efforts to organize and broaden the role of cooperatives in providing credit and inputs and marketing of output were not met with any significant success.

\subsection{Brazil}

Brazil is endowed with vast agricultural resources. The country's agriculture is well diversified, and the country is largely self-sufficient in food [46]. One of the major agricultural policies in Brazil that has sustained and promoted self-sufficiency and export of agricultural products in the country is strong support intervention in the credit sector via interest rate subsidies and the requirement that banks allocate at least $29 \%$ of their demand deposit to agricultural lending. The amount of support for agricultural credit in Brazil increased from US\$7 billion in 2001 to US\$73.4 billion in 2011/2012 [46]. Public bank sector continues to play an important role. While access by individuals to financial services still remains at a low level, the increase in the number of savings cooperatives and microfinance credit institutions is helping to expand this reach [47]. Agricultural credit has been directed toward financing crop and livestock production, as well as capital investments in agricultural infrastructure and equipment. Capital investments have included machinery for planting and harvesting and for the processing of livestock products and pastureland expansion. Over three-quarters of the investment credit disbursed between 1985 and 2006 has been issued to the livestock sector, boosting livestock's credit investments by $4.7 \%$ annually, more than double the investment credit allocations for crops during the same period. The livestock sector's greater growth in investment credit indicates Brazil's priority of modernizing livestock production [48].

Agriculture sector accounted for $10.10 \%$ of Brazil's GDP and around $23 \%$ of total labor force in 2000 . Rural credit programs are one of the main instruments of Brazilian agricultural policy and these are mainly organized by the Ministry of Agrarian Development [47]. Rural credit is provided by credit cooperatives and by the commercial banks, participants in the National Rural Credit System (NRCS). NRCS was created in 1965 to quicken capital formation in exportable farm products [48]. The rules and conditions to be observed regarding loans are established by the National Monetary Council (NMC), which is a body connected to the Finance Ministry and the application of these rules and conditions is examined by the Central Bank [49].

Overall, agricultural credit transactions for financing production can be found in two forms in Brazil: formal credit from financial institutions or credit from nontraditional credit market agents (trade credit) by contractual farming with trading and processing companies [50]. In the first case, the producers are able to contract farm credit with banks and credit unions. In Brazil, there is a subsidized credit modality for family farming through the National Family Farming Program and there is also the restricted credit with preferential rates provided to farmers who do not fit into family farming by the banks associated with the National Farm Credit System [50].

Rural credit is one of Brazil's most traditional ways to support agriculture. Rural credit is an important source of funding for Brazilian agriculture, as well as a key policy instrument in the country. Rural credit is subsidized by the government [4]. The Ministry of Agriculture estimates that approximately $30 \%$ of the resources needed in a typical harvest year are funded by rural credit. The remaining $70 \%$ come from producers' own resources, as well as from other agents of agribusiness (such as trading companies) and other market mechanisms (such as legal instruments that enable the pre-sale of production) [4]. The government of Brazil aims to develop in some areas with rural credit application. In some areas, however, farmers have difficulty obtaining credit. Because of the rural credit program, farmers can obtain financial advantages during production and marketing stages. Because of this, rural credit includes investing, producing, and marketing commodities. Government subsidized rural credit represents about a third of the total credit needs of the agricultural sector in Brazil. The private sector (private banks, input providers, brokers, and farmers) provides the rest, a change from pre-1994 reforms when the Brazilian Government provided the bulk of the credit needs [48]. The rural credit program works by granting subsidized interest rates of $3 \%$ for small farmers and family farmers, and a general agricultural credit rate of $6.75 \%$. This could be compared to the average lending rate of 39\% in Brazil [43]. Apart from rural credit program, production credit loans are used to buy inputs for planting and are repaid when the production is sold. Other credit policies in Brazil are marketing credit programs, commodity price support programs, investment credit [46].

Recently, commercial agriculture has had access to commercial loans; only the National Rural Credit System finances family agriculture in Brazil. Distribution of the resources of National Rural Credit System can be seen in Table 1. Credit institutions, banks, and cooperatives 
contributed to the rural credit system by granting loans with subsidized interest rates to farmers. From 2002 to 2010, private banks increased in the system. Even though still small, the share of credit cooperatives in the distribution of rural credit is growing.

Table 1. The Share of Origin and Use of National Credit System in Brazil (\%).

\begin{tabular}{lllll}
\hline Origin of Resources & $\mathbf{2 0 0 2}$ & $\mathbf{2 0 0 6}$ & $\mathbf{2 0 0 8}$ & $\mathbf{2 0 1 0}$ \\
\hline $\begin{array}{l}\text { Compulsory Resources (Levied from } \\
\text { Banks) }\end{array}$ & 53 & 46 & 47 & 47 \\
$\begin{array}{l}\text { Rural Saving Account } \\
\text { Brazilian National Economic and }\end{array}$ & 13 & 19 & 26 & 30 \\
$\begin{array}{l}\text { Social Development Bank } \\
\text { Other Public Resources }\end{array}$ & 17 & 8 & 1 & 1 \\
Free (Voluntary) Resources & 5 & 7 & 6 & 6 \\
$\begin{array}{l}\text { Use of Resources } \\
\text { Federal Public Banks }\end{array}$ & 55 & 51 & 51 & 50 \\
$\begin{array}{l}\text { States Public Banks } \\
\text { Private Banks }\end{array}$ & 2 & 2 & 4 & 2 \\
Credit Cooperatives & 36 & 41 & 36 & 39 \\
\hline
\end{tabular}

Source: [44]

\subsection{Africa}

African countries generally should be self-sufficient in food production. Agriculture is the largest contributor to Africa's GDP, accounting for over $35 \%$ of the total output. With the exception of some oil producers, agriculture is also the major source of income for most of the African countries. More precisely, about $70 \%$ of Africa's population engages in agricultural cultivation. Most of the African countries have substantial part of their exports in agricultural products. Some of the African countries that have large population like Nigeria, Egypt and South Africa are supposed to be good markets for domestic production of agricultural products. Unfortunately, the continent still imports about $50 \%$ of their food consumption. Aside from the problem of poor access to modern technology by the peasant farmers in the African countries, the major problem of agricultural development is low investment or poor finance. Access to credit facilities has also been identified as the direct solution to increasing investment agriculture in Africa [43]. This is true for underdeveloped African countries. It is widely known that credit is a crucial factor in agricultural production and in many cases may be a limiting factor in small farms for all countries.

Generally, agricultural credit can be obtained from formal and informal sources in African countries. The proportion of credit varies country by country. The informal type of agricultural credit refers to credit from moneylenders, friends, relatives and the like. Whenever small farmers need emergency loans or small investment funds, they often resort to moneylenders. In the formal setting of most developing countries, commercial banks and other specialized agencies are charged with the responsibility of providing credit to farmers. Table 2 shows the share of commercial banks' lending to agricultural sector in the selected African countries.
Table 2. Share of Commercial Bank Lending the Agricultural Sector in Africa (\% of Total Portfolio).

\begin{tabular}{llllllll}
\hline Years & Nigeria & Kenya & Mali & Lesotho & Egypt & Rwanda & Sudan \\
\hline 1995 & 17.49 & 48.80 & 10.12 & - & - & - & - \\
2000 & 8.07 & 6.57 & 11.30 & - & - & - & - \\
2005 & 2.46 & 6.25 & 19.30 & - & 4.70 & - & 17.10 \\
2006 & 1.96 & 5.38 & 55.67 & - & 7.30 & - & 12.00 \\
2007 & 3.11 & 4.08 & 24.72 & - & 5.30 & - & 13.90 \\
2008 & 1.36 & 3.60 & 19.75 & 0.31 & 5.20 & 4.20 & 12.40 \\
2009 & 1.50 & 3.08 & 27.96 & 1.90 & 4.90 & 4.97 & 13.94 \\
2010 & 1.70 & 3.03 & 21.12 & 8.17 & 2.90 & 5.24 & 11.01 \\
2011 & 3.50 & 7.58 & 22.11 & - & 1.90 & 3.38 & 12.35 \\
\hline
\end{tabular}

Source: [43]

Available data show that the agricultural sector in Nigeria, Kenya, Mali and Sudan benefited substantially from commercial banks' lending from 2005. Short term credit and intermediate term credit are used for obtaining farm inputs such as fertilizer, improved seeds, breeding livestock and farm machinery, while long term credit is used for real-estate financing [48]. Credit inadequacy has been a problem militating against the development of the rural farmers in the world at large and Nigeria in particular. The credit inadequacy has been a major problem militating against the effectiveness and development of rural farmers [49]. However, most banks closed some of their rural branches which compounded the problem of rural farmers' credit access. The main reason for this was the inability of the farmers to cope with the prevailing interest rate and other credit requirements, which made the banks operate at a loss in such areas [50]. Banks are unwilling to lend farmers credit because of the inherent risk associated with the agricultural sector and inability of farmers to provide necessary collateral. Moreover, banks are uncomfortable with the high cost of credit administration to farmers. Farmers are also unwilling to procure credit from banks because of lengthy and cumbersome loan procurement procedure, high cost of bank loan, untimely disbursement of loan by banks and long distance from source of loan $[50,51]$.

The informal sources of credit to smallholder farmers as identified in the study area were family or friends, money lenders, produce buyers and farmers' cooperatives, while the formal sources of credit were Nigerian agricultural cooperative and rural development bank, microfinance banks and commercial bank. Nigerian government has embarked on good credit policies to ensure availability and accessibility of credit to enhance rural farming, such as rural banking program, micro finance banks, agricultural credit guarantee scheme and Nigeria agricultural co-operative and rural development bank [49].

\subsection{Turkey}

Agriculture is an important sector for Turkey in terms of social and economic aspects. In order to create a sustainable, competitive and organized agricultural sector, Turkey needs to utilize its resources efficiently and effectively. For developing such an agricultural sector, farmers of all sizes 
should have better access to finance [55]. Agricultural employment and export account for $20 \%$ and $5 \%$ of Turkish GDP, respectively. Turkey had 68 billion \$ agricultural output in 2014. In spite of its importance and contribution to the economy, Turkish agricultural sector consists of more than 3 million farm holdings who have a very small share in total loans [56]. The share of agricultural loans among total loans varied from $\% 3$ to $\% 4$ in the last 5 years [57]. Because of the small scale of family farms, there is lack of access to finance. Besides, their access to agricultural supports and subsidies is also restricted. Eventually, quite a number of farms try to get operating funds from informal credit sources with high costs and heavy conditions.

Farmers get agricultural credits from various sources. They can be classified as two groups, formal and informal sources. The agriculture bank (Ziraat Bankası), commercial banks (domestic and foreign-owned and operated), and agricultural credit cooperatives (ACC), agricultural sales cooperatives and some cooperatives such as Pankobirlik related to sugar processing, are major formal credit suppliers, while other individuals and institutions constitute informal resources. Tradesman, money brokers, commissioners, wealthy farmers, and money lenders are among the informal credit sources, all of which are short term borrowing providers with high interest rates and heavy payment conditions $[15,58]$. Informal sources consist of money lender, land owners and they require short term and high interest rate for their credit. They are not working off the record. They have a great power to prevent development of credit market. Generally some farmers who cannot get guarantee, prefer to use these credit sources. Informal credit sources will decline by facilitating access to credit and development of credit market.

Banks are the most important financial sources in agriculture in Turkey. Especially, private banks are attached to agriculture due to profit margin and potential of the sector. So, banks operated in the agricultural sector with specialized agricultural credits and credit packages. Private banks discovered the potential in agriculture sector in time and $100 \%$ share of public banks in total agricultural loans has shown a sharp decline. In some banks, agricultural units have been created.

Agricultural Bank of the Republic of Turkey (Ziraat Bankası) has supplied almost all agricultural credits in Turkey since mid-2000s. In recent years, other banks have entered the sector, so Agricultural Bank's share fell to 65$75 \%$. The share of Ziraat Bank in agricultural lending market went down to around $66 \%$ in spite of the monopoly of the bank on disbursement of subsidized loans and agricultural subsidies.

In the Table 3 , the share of private banks has risen from $\% 33.8 \%$ to $35.9 \%$, between 2008 and 2009 . In the following years, other public banks (Halkbank and Vakıfbank) have supplied important financial source to the sector and public banks' share has fallen. So public banks' share declined to $25.7 \%$ in 2011 and has been aound $33-36 \%$ since then.
Table 3. Agricultural Credits from the Public and Private Banks (1 US $\$=$ 2.9 TL).

\begin{tabular}{lllll}
\hline \multirow{2}{*}{ Years } & \multicolumn{2}{l}{ Public Banks } & \multicolumn{2}{c}{ Private-Commercial-Banks } \\
\cline { 2 - 5 } & $\mathbf{1 0 0 0}$ TL & $\mathbf{\%}$ & $\mathbf{1 0 0 0}$ TL & \% \\
\hline 2007 & 6.637 .391 & 66,2 & 3.392 .659 & 33,8 \\
2008 & 8.247 .517 & 64,1 & 4.609 .922 & 35,9 \\
2009 & 10.491 .260 & 70,2 & 4.463 .480 & 29,8 \\
2010 & 16.711 .584 & 73,3 & 6.099 .582 & 26,7 \\
2011 & 22.979 .394 & 74,3 & 7.951 .398 & 25,7 \\
2012 & 22.748 .281 & 69,8 & 9.858 .345 & 30,2 \\
2013 & 23.253 .328 & 63,8 & $13,215,714$ & 36,2 \\
2014 & $29,449,415$ & 64,2 & $16,415,912$ & 35,8 \\
2015 (3. Quarter) & 39.262 .662 & 66,7 & 19.639 .742 & 33,3 \\
\hline
\end{tabular}

Sources: [59]

The Bank of Agriculture (Ziraat Bankasi) was a stateowned bank in Turkey and was founded in 1863. As a major institution from formal credit suppliers, Ziraat Bankası was distributing government based funds directly or through other channels until 2002. The Bank's organizational structure is completely transformed into joint-stock company in that year. When the Reform Policy Program was put into practice, the Bank reduced its agricultural loans portfolio sharply. Today, the Bank's agricultural direct lending operations have been channeled mainly to larger farms and state-owned holdings, despite current regulation that address small farm holders as target client. In this context, the Bank can also extend credits to individual farmers directly for middle or long term provided that customer meets restrictive credit requirements [60].

Ziraat Bankasi is the second biggest Turkish bank in terms of total assets. Ziraat Bank had TL 207.5 billion (\$71.5 billion) of total assets at the end of 2013. It cooperates with national and international corporations to provide more appropriate low-cost and long maturity investment credit and to help finance the working capital requirements of SMEs and medium sized holdings, which make up an important portion of Turkey's commercial and industrial operations. Its lending to the agricultural sector had amounted to TL 22.3 billion ( $\$ 7.7$ billion) with a total of 566,665 credit customers at 2013 [61]. Customers had the opportunity to obtain agricultural operating and investment loans with annual interest rates varying from $0 \%$ to $8.25 \%$ within subsidy ratios set on the basis of production scopes in relevant decrees.

While total agricultural loans disbursed by state-owned banks reached a level of 20 billion TL for 2012, they declined in their share in total agricultural loans in the sector, indicating that the growth in total of such loans mainly results from the increase in agricultural portfolios of private banks (domestic and foreign). After a while, banks' perception of agricultural lending as "risky" has been replaced by the following approach: "a profitable business line when managed in a professional manner and the risks are put under control". Confirming this approach, rate of nonperforming loans in agriculture sector in 2013 reached as $3.6 \%[56]$.

The Agricultural Credit Cooperatives (ACC) operated 
under Ziraat Bankasi until May 17, 1977, when the Central Union of Agricultural Credit Cooperatives of Turkey was officially opened. Since then, Ziraat Bankasi has had no managerial responsibilities towards the ACC of Turkey, yet it has been acting as the ACC's financing bank. Even though the ACC went under the overall responsibilities of the Ministry of Food, Agriculture and Livestock for a decade (1985-1995), today it is an independent farmer organization which owes its current democratic structure to the law number 5330 enacted in 2005. The Agricultural Credit Cooperatives of Turkey renders service to its 1.1 million members with 16 regional unions and 1625 cooperatives, 188 service offices and 7244 personnel [62].

ACC provides short term and medium term credits to its memberships. Short term credits are aimed at meeting the needs of small farm holders to procure seed, animal feed, chemical fertilizer, pesticides and fuel. They are mostly one year, fixed term credits supplied for working capital and agricultural investment needs of the cooperative members. Medium term credits are those that aim to invest in fixed assets such as agricultural vehicles and equipment, fruit seedlings, apiculture, aquaculture products equipment, sericulture, and poultry farming, cattle and revenue animals for three-year term. On the other hand, ACCs also engage in other activities related to agriculture such as production, marketing, insurance and grocery [62]. Although ACCs maintain crucial role in financing agricultural sector, a recent study revealed that these cooperatives are inefficient and oldfashioned organizations operating under the supervision of state bodies with heavy government bureaucracy and lack of well trained staff. Unit cooperatives experience shortages in providing sufficient sources for credit demands and work with costly inputs. Cooperative members in many cases default on paying the principal and installments on a timely basis.

\section{Conclusions}

Based on findings of this study, the following results and recommendations are made:

a The American Farm Credit System, the most organized in the world, is a network of lending institutions and related services organizations specialized in providing credit to farmers, ranchers, and producers.

b This system has connected some important lending institutions such as commercial banks, credit associations, and agricultural credit banks which provide a variety of credit programs.

c They are governed by boards of directors elected by the stockholders of each institution. These institutions are regulated by the Farm Credit Administration (FCA). System banks formed Federal Farm Credit Banks Funding Corporation and these corporations have facilitated raising funds in the financial market markets and regulating offering loan able funds, bonds and discount notes. In fact, the interest rate is not determined by FCA. d This rate can be fixed or variable. This interest rate is determined by cost of funds, operating expenses, and provisions for loan losses.

Farm Credit System has provided increasing level of support for the agriculture sector. FCA has helped improve liquidity performance of the banks and strengthened their administrative and contingency funding plan. In the Farm Credit System, there is a linkage between all institutions. The history of this relationship dates back to 1916. Over the years, the types of borrowers have increased and this system has continued to support the agricultural sector through various Acts.

In Turkey, most of the farmers are small producers engaged in agricultural activities in areas of widely varying potential. After 2000, there has been increased competition in the agricultural credit market. Until then, Agricultural Bank was dominant with a market share of $95 \%$. After the privatization period, some commercial banks started to offer loan to the farmers who depended on recovery of the economic conditions. The main question is whether farmers will benefit enough from the credit facilities. This question is not answered by only looking at the credit market structure. It must consider the entire farming system with supporting regulations such as increasing farm land size, commercial farming, etc.

There are differences between the rural areas and the relationship of agricultural credit institutions between Turkey and the US. One of them is that the former's agricultural credit market is mostly internal and there is open free market. In this market, commercial banks are a new player and are trying to increase their market share by giving more loans to farmers. The latter has integrated institutions such as banks, cooperatives and state institutions in the farm credit system and has continued to develop thanks to large farms and developed market.

In Turkey, although privatization of the agricultural credit market has started, government has offered subsidized credit through the Agricultural Bank. Other banks have higher interest rate and this is why some farmers prefer to receive credit from Agricultural Bank. Commercial banks have tried to meet farmers' demand for their products through promotional activities and quick credit evaluation and disbursement, determination of loan maturity in line with the production, client and field visits, easy guarantee etc. They are focused on how to increase the types of eligible borrowers.

The other difference between the Turkish and US system is the organizational model. There are many farm credit cooperatives in the US. In Turkey, Agricultural Credit Cooperatives generally depend on Agricultural Banks for funds and are not developed as much as those in developed countries.

Another difference between the two countries is that in general, the interest rates on agricultural credits are not fixed in the US; it varies based on the cost of money. This situation is almost the same for Turkey, but there has been increased amount of subsidized credit through Agricultural Bank for 
irrigation, breeding of livestock, seed etc. The amount of these credits changes depend the on government's decision each year.

There is also a big difference about cooperatives banking experiences. Turkey, unfortunately, cannot establish cooperative banking system like US. In examining the Brazilian farm credit system, some resemblance is seen in rural credit system. Turkey and Brazil have almost the same history of struggle with economic problems such as high inflation rates and unemployment, high percentage of agriculture in GNP, and the like. Nowadays, they have solved all problems and provide low interest credit. They have preferred to open the agricultural credit sector in order to control risk. Unfortunately, agricultural cooperatives are not still effective within the system. Turkish government tends to provide support with direct payment and subsided credit. In Brazilian farm credit system, rural credit is very important and it is granted by government.

It is very important to extend credit to all of the suitable farms. If farms become more diverse and more profitable, they will increase their credit demand and finally agricultural credit market can expand like in developed countries. All regulations depend upon on the development of farming sector and farmers. That is why it is highly recommended that farms form collective structure. All developed countries have high number of cooperatives in the farming sector. For instance, US agricultural credit system has highly developed institutional arrangements, commitment to serve for many years by the federal government for the agricultural sector. All institutions and organizations involved in the system are responsible for each other, and this increases the responsibility for compliance with the aims of sustainable planning and development.

Agricultural farms have an important advantage within the overall structure of US agriculture credit system. All elements in the organizational model work towards increasing their contributions to the development of the agricultural sector. Within the system, the scale of business and volume of production are important, attracting cooperatives, banks and credit institution. Related to the agricultural sector, problems and crisis intervention are addressed instantly by official institutions which are administratively connected directly to the US Congress. Agriculture has a priority in the US economy and cooperative banks related to agricultural facilities have economic advantages such as tax incentives, providing sustainable agricultural production.

In this context, the following recommendations are offered for improvement of the Turkish agricultural credit system:

a Turkey's agricultural financing and particularly credit applications require macro-planning. It requires full and comprehensive coordination of all credit institutions such as the state banks and manufacturers, agricultural organizations, inter-industrial organizations and civil society.

b Agriculture and agricultural structures should be strengthened with regards to infrastructure, classification, organization and management.

c Increased fund-raising efforts for the agricultural sector is essential.

d Private banks should be further encouraged in their penetration into the agricultural credit market; farmers would benefit from more competition among lenders.

e Agricultural production planning should include consideration of the needed agricultural credit. Its scope should widen to encompass rural and vocational education related to capital management and organization models. There are some examples in developed or developing countries such as Nigeria, India and rural China to be looked closer for this purpose.

f Agricultural credit cooperative and their banks should be developed especially for small scale farmers. We saw the benefit of this for Brazil and EU countries.

g A central financial institute whose duty would be to determine, plan and distribute the credit amount for agriculture should be established. Establishing this system is important for the competition and regulation in the future.

$\mathrm{h}$ This institute must be independent and observe financial development all over the world. The membership of this institute should consist of representatives of banks, cooperatives, rural financier and farmer organizations, similar to the US.

\section{Acknowledgements}

This study was conducted while Erdogan Gunes was a visiting scholar in the School of Business at Ithaca College and supported by a scholarship from Scientific and Technological Research Council of Turkey (TUBITAK) program 2219.

\section{References}

[1] Monke J. (2015/a). Agricultural Credit: Institutions and Issue, Congressional Research Services Report. April /8 /2015.

[2] https://www.farmcreditfunding.com/farmcredit/.

[3] Kumar, S. M. (2012). Does Access to Formal Agricultural Credit Depend on Caste? World Development Vol. 43, pp. 315-328, 2013 http://dx.doi.org/10.1016/j.worlddev.2012.11.001.

[4] Assunção, J., Gandour, C., Rocha, R., Rocha, R. (2013). Does Credit Affect Deforestation? Evidence from a Rural Credit Policy in the Brazilian Amazon CPI (Climate Policy Initiative) Technical Report. Rio.

[5] OECD (2013). Agricultural Policy Monitoring and Evaluation 2013 OECD Countries and Emerging Economies-Brazilwww.oecd.org/publishing/corrigenda.

[6] Tang, S., Guan, Z., Jin, S. (2010). Formal and Informal Credit Markets and Rural Credit Demand in China, Agricultural \& Applied Economics Association 2010 AAEA, CAES, \& WAEA Joint Annual Meeting, Denver, Colorado, July 25-27, 2010. 
[7] Turvey, C. G., Kong, R., and Huo, X. (2009). Borrowing amongst Friends: The Economics of Informal Credit in Rural China, Paper Presentation IAAE Beijing August 2009.

[8] Han, J. (2004). The Creation of a Favorable Environment for Investment in Rural China: Current Situation and Future Prospects, China in the Global Economy Rural Finance and Credit Infrastructure in China, OECD workshop publication.

[9] Scott, D. and Druschel, K. (2004). Institutional Issue and Prerequisites for Efficient Savings Mobilization and Allocation in Rural and Lesser Developed Regions in China, China in the Global Economy Rural Finance and Credit Infrastructure in China, OECD workshop publication.

[10] Swinnen, J. F. M. and Gow, H. R. (1999). Agricultural Credit Problems and Policies during the Transition to a Market Economy in Central and Eastern Europe, Food Policy 24 (1999) 21-47.

[11] Jansson, K. H., Huisman, C. J, Lagerkvist, C. J, and Rabinowicz, E. (2013). Agricultural Credit Market Institutions A Comparison of Selected European Countries, Factor Markets Working Paper No. 33/January 2013.

[12] Ho, G. (2004). Rural Credit Markets in Vietnam: Theory and Practice, Gary Krueger and Vasant Sukhatme Department of Economics Macalester College.

[13] Gunes, E. and Artukoglu, M. M. (2010). Agricultural Credit Efficiency and Applications In Turkey During Global Financial Crisis, Turkey IX. Agricultural Economics Congress, p. 795-801, Sanlurfa, (In Turkish).

[14] Nagendra, S. and Reddy, C. L. K. (2015). An Analysis of Agricultural Credit Structure in India, Indian Streams Research Journal Volume 5, Issue-1, February.

[15] Tanrivermis, H. and Bayaner, A. (2006). Members' Perception and the Role of Agricultural Credit Cooperatives in Agricultural Finance in Turkey, New Medit N. 3/2006.

[16] Bojnec, Š. (2011). Agricultural and Rural Capital Markets in the EU Candidate Countries: Croatia, the Former Yugoslav Republic of Macedonia and Turkey, Comparative Analysis of Factor Markets for Agriculture Across the Members States, Factor Market Working Paper No. 8, October 2011.

[17] Nwaru, J. C., Onyenweaku, C. E., and Nwosu, A. C. (2006). Relative Technical Efficiency of Credit and Non-credit User Crop Farmers, African Crop Science Journal 14 (3): 241-51. Farm Credit Second Quarter 2015, Quarterly information Statement of Farm Credit System.

[18] Etonihu, K. I., Rahman, S. A., Usman, S. (2013). Determinants of Access to Agricultural Credit Among Crop Farmers in a Farming Community of Nasarawa State, Nigeria, Journal of Development and Agricultural Economics, Vol. 5(5), pp. 192-196, May, 2013 DOI 10.5897/JDAE11.126.

[19] Akram, W. (2008). Constraint's Analysis of Agricultural Credit Use: Implications for Poverty Reduction in Pakistan, A Dissertation Submitted to the Department of Economics University of Sargodha.

[20] Bishoff, J. M. (2008). Agricultural Finance and Credit, ed., NY Nova.

[21] Monke, J. (2008). Agricultural Credit: Institutions and Issue, Chapter: 5, Agricultural Finance and Credit, NY Nova.
[22] http://www.farmcreditnetwork.com/about/history

[23] http://www.farmcreditnetwork.com

[24] Monke J. (2015/b). Agricultural Credit: Institutions and Issue, Congressional Research Services Report. April /6 /2015.

[25] http://www.farmcreditfunding.com/ffcb_live

[26] http://www.farmcreditfunding.com/farmcredit

[27] http://www.farmcreditfunding.com/farmcredit/current/Informa tionStatement.pdf?uniq= 1444748408705 .

[28] http://www.aba.com/Industry+Issues/issues_ag_menu.htm

[29] http://www.icba.org.

[30] OECD (2004). China in the Global Economy Rural Finance and Credit Infrastructure.

[31] Empel, G. V. and Smit, L. (2004). Development and Sustainable Credit Cooperatives in China, China in the Global Economy Rural Finance and Credit Infrastructure in China, OECD workshop publication.

[32] Lin, Y. F. (2003). Information, Informal Finance and SME Financing, China Center for Economic Research, Working Paper, No. C2003025.

[33] Gale, F. and Collender, R. (2006). New Directions in China's Agricultural Lending, USDA Electronic Outlook Report From The Economic research Service, 2006.

[34] Zhang, H. 2004. The System of Chinese Rural Financial Organizations: Achievements, Shortcomings and Institutional Renewal, OECD Workshop Publishing.

[35] Tang, S. (2008). The Relationship between Credit Access and Agricultural Economy, Journey of Northeast Agricultural University, Edition of Social Sciences. No. 1.

[36] Jiang, S. J. (1984). How Are the Various Types of Non-Bank Credits in Rural Areas at Present to be treated? Rural Finance Research Institute, Guangxi Zhuang Autonomous Region, July.

[37] Feder, Gershon, Lawrence J. Lau, Justin Y. Lin, and Xiaopeng Luo. (1990)." The Relationship between Credit and Productivity in Chinese Agriculture: A Microeconomic Model of Disequilibrium." American Journal of Agricultural Economics. Vol. 72(5): 1151-1157.

[38] Yao, Y. J., and Chen, D. F., (2005). The Development of China Rural Informal Finance-Theory and Empirical Study, China Rural Economy. No. 8: 45-51.

[39] He, G. W, (2007). The Diversities and Strategy of China Rural Financial Institutions, The Observation of China Rural Finance, P 12-20.

[40] Godara, R. L., Singh, P., Singla, S. (2014). Agriculture Credit in India: An Analytical Study, International Journal of Latest Trends in Engineering and Technology (IJLTET), Vol. 3 Issue 3 January 2014.

[41] Golait, R. (2007). Current Issues in Agricultural Credit in India: An Assessment, Reserve bank of India Occasional Papers, 28(1), summer.

[42] Gandhimathi, S. (2012). Distribution of Agricultural Credit in the Pre and Post Reform Period, IJMIE, Vol: 2, Issue: 9. 
[43] Mohan, R. (2004). Agricultural Credit in India: Status, Issues and Future Agenda, November Reserve Bank of India Bulletin 2004.

[44] Kishore, N. T. K. (2012). Agriculture Credit in India: An Integrated Rural Credit Approach, International Journal of Scientific and Research Publications, Volume 2, Issue 3, March 2012.

[45] Subbarao, D. (2012). Agricultural Credit-Accomplishments and Challenges, Governor of the Reserve Bank of India, at the thirty years anniversary celebration of NABARD, Mumbai.

[46] Salami, S. and Arawomo, D. F. (2013). Empirical Analysis of Agricultural Credit in Africa: Any Role for Institutional Factors? African Development Bank Group Working Paper Series. No: 192, African Development Bank, Tunis, Tunisia.

[47] Westercamp, C., Nouri, M., Oertel, A. (2015). Agricultural Credit: Assessing the Use of Interest Rate Subsidies, AFD Sustainable Development Department, A Savoir 29.

[48] Rada, N. and Valdes, C. (2012). Policy, Technology, and Efficiency of Brazilian Agriculture, USDA Economic Research Service Report Number 137.

[49] Sobrinho, G. R. C. da C. (2001). Agricultural Financial Policies in Brazil and the USA Comparison, Institute of Brazilian Issues The Minerva Program Fall 2001.

[50] Almeida, L. F de, Zylbersztajn, D. and Klein, P. G. (2010). Determinants of Contractual Arrangements in Agricultural Credit Transactions, R. Adm., São Paulo, v. 45, n. 3, p. 209220, jul./ago/set. 2010.

[51] Adebayo, O. O., and Adeola. R. G. (2008). "Sources and Uses of Agricultural Credit by Small Scale Farmers in Surulere Local Government Area of Oyo State." Anthropologist 10 (4): 313-4.

[52] Ijioma, J. C. and Osondu, C. K. (2015). Agricultural Credit Sources and Determinants of Credit Acquisition by Farmers in Idemili Local Government Area of Anambra State, Journal of Agricultural Science and Technology B 5 (2015) 34-4, doi: 10.17265/2161-6264/2015.01.004.
[53] Ljere, M. O., and Mbanasor, J. A. (1998). Agricultural Credit and Economic Development, In Readings in Agricultural Finance, edited by Ijere, M. O., and Okorie, A. Lagos: Longman Nigeria Plc., 111-5.

[54] Okorie, A. (1998). Management of Risk and Default in Agricultural Lending, In Reading in Agricultural Finance, edited by Ijere, M. O., and Okorie, A. Lagos: Longman Nigeria Plc., 90-105.

[55] Tasci, C. (2015). Trends And Issues in Financing Agriculture: A Global Perspective and Look at Turkish Case, Finansal Araştırmalar ve Çalışmalar Dergisi, Cilt 7, Sayı 12, Ocak 2015, ISSN 1309-1123, ss. 173-195. DOI: $10.14784 /$ jfrs.61987.

[56] Yildiz, M. and Kocoglu, E. (2014). A Different View on Agricultural Banking, Agrotime. 8-15.

[57] http://ebulten.bddk.org.tr/ finturk.

[58] Bayaner, A. Bor, Ö. 2006. Do the Policies Always Have the Same Consequences? The Impact of Direct Income Support on Wheat Production: Case of Turkey New Medit, Mediterranean Journal of Economics, Agriculture and Environment. No. 1.

[59] BBDK (2012-2015). Financial Indicators www.bbdk.com.

[60] Oskam, A., Bursell, A., Temel, T., Beckum, S. V., Longworth, N., Vilchez, M. (2004). Turkey in EU, Consequences for Agriculture, Food, Rural Areas and Structural Policy Report, Holland.

[61] Ziraat Bankasi, (2013). More Than a Bank for a Hundred and Fifty Years, http://www.ziraat.com.tr/en/InvestorRelations/Documents/An nualReports/AnnualReport2013.pdf, annual report 2013.

[62] ACC (2014). The web page of Central Union of Turkish Agricultural Credit Cooperatives. Available at: http://int.tarimkredi.org.tr/index.php/en.html. 